\title{
Porifera (sponges) of Mermaid, Scott and Seringapatam Reefs, north Western Australia.
}

\author{
Jane Fromont ${ }^{1}$ and Mathew A. Vanderklift ${ }^{2}$ \\ ${ }^{1}$ Department of Aquatic Zoology, Western Australian Museum, Locked Bag 49, Welshpool DC, WA6986, Australia. \\ Email: jane.fromont@museum.wa.gov.au \\ ${ }^{2}$ CSIRO Marine and Atmospheric Research, PO Box 5, Wembley, WA 6913, Australia.
}

\begin{abstract}
A quantitative survey documenting the diversity and abundance of sponges at Mermaid, Scott and Seringapatam Reefs, north Western Australia, was conducted in September 2006. Four reef habitats (fore reef slope, channel, lagoon and intertidal reef flat) were surveyed by recording numbers of sponge individuals on replicate transects, providing baseline data of sponge species present and their abundance. In total 132 sponge species were recorded from these reefs. The majority of the species found (79) were unique to one of the reefs, with only 14 species found at all three reefs. A clear difference in the composition of the sponge assemblages between Mermaid and Scott Reefs was detected, which appears to be strongly influenced by the presence of infrequently recorded (rare) species. Intertidal reef flat habitats had lower species richness than subtidal habitats $(<3$ species at intertidal stations compared to between 6-21 species at subtidal stations). Channels were distinct from other subtidal habitats and were characterized by high abundances of a few common species. Over half of the species found in the study were rare with 56\% having five or fewer individuals recorded from all locations in the study. This is the first documentation of the sponge fauna from these reefs and only the second study to date to examine the sponges found on the oceanic reefs off north Western Australia.
\end{abstract}

Keywords: Porifera, marine sponges, Australia, species richness, abundance, diversity.

\section{INTRODUCTION.}

Sponges were collected as part of a Western Australian Museum survey of Mermaid Reef (Rowley Shoals), North and South Scott Reefs, and Seringapatam Reef, north Western Australia, undertaken in September 2006. These oceanic atolls are situated on the edge of the continental shelf approximately $300 \mathrm{~km}$ off the coast of northwestern Australia. Their great distance from land means they are in oceanic waters not impacted by terrestrially derived sediments and water clarity is high. They can be subjected to cyclones, with Scott Reef severely impacted by Cyclone Fay in 2004. Scott Reef also experienced a massive bleaching event in 1998 (Heyward et al., 1999).

No previous studies of sponges have been conducted in these reef systems. Hooper (1994) surveyed the coral reef sponges of the more northern oceanic reefs of Ashmore Reef, Cartier Island and Hibernia Reef, of which the southernmost, Cartier Island, is approximately
$150 \mathrm{kms}$ northeast of Seringapatam Reef. Prior to Hooper's study no work had been undertaken on the sponge fauna of the oceanic coral reefs on the northwestern continental margin of Australia.

Hooper (1994) found that although the three coral reef systems he examined were in close proximity to each other (less than approximately $50 \mathrm{~km}$ apart) they did not contain similar sponge species. Therefore in our study we were interested to determine if sponge species composition differed between Mermaid, Scott and Seringapatam Reefs.

The aims of this study were threefold, firstly to determine the sponge species present and their abundance at each of the atolls studied. Secondly, sponge species assemblages were compared between the habitats and atolls surveyed to determine if species composition differed significantly between atolls or between different habitats. Finally, non-parametric methods were used to estimate the possible number of species that may occur in the area. 


\section{METHODS.}

\section{Field sampling methods.}

A total of 45 stations were surveyed (24 at Scott Reef, 16 at Mermaid Reef, and 5 at Seringapatam Reef).

Stations were chosen to represent four habitat types: intertidal reefs, fore reef slope, lagoon and channels. A list of stations, habitat descriptions and locality maps with the stations marked are presented in the Station and Transect Data section of this volume.

Subtidal station surveys were carried out on SCUBA or snorkel. Transect lines $(5 \times 1 \mathrm{~m}, \mathrm{n}=3$, total area $15 \mathrm{~m}^{2}$ ) were laid over the dominant habitat parallel to the depth contour and all sponges were counted. At subtidal forereef slope and lagoon stations three transects were laid between nine and $15 \mathrm{~m}$ depth $(12 \mathrm{~m}$ mean sea level (msl)) and a second set of three transects were laid at three to eight $\mathrm{m}$ depth $(5 \mathrm{~m} \mathrm{msl})$. The exact depth sampled depended on the height of the tide at the time of diving. Only one depth was sampled at two stations where there was a reduced depth profile (eg. bommies in the lagoon). Transect lengths were estimated by eye in channels due to the difficulty of laying and retrieving tapes in strong currents. Counts of individual sponges were determined as per the methods used at stations where transect tapes were laid.

Intertidal station surveys were carried out by reef walking at low tide. Three transects were surveyed when the width of the reef flat was narrow ie. considered to comprise one habitat with all organisms exposed at low tide for a similar length of time. If the reef flat was wide three transects were surveyed near the low tide mark, and three transects were laid inshore where organisms are exposed to air for longer at low tide.

\section{Specimen collection.}

A voucher specimen of each sponge species was collected: voucher specimens were also collected if there were morphological or colour differences from previous vouchers. Specimens were separated immediately in situ to avoid contamination by mucous exudation from other sponges, or possible spicule loss. After collection, records were made of natural colour, changes in coloration on exposure to air, mucous exudation, and gross morphology for each specimen collected. Specimens were preserved individually in $75 \%$ ethanol, photographed on deck, and some species were photographed in situ.

Preliminary sponge identifications were undertaken at the end of each survey day by preparing bleach preparations of the skeletons and spicules of each species collected. These were examined with a Leitz DME compound microscope with a calibrated eyepiece graticule. Details and sizes of spicule and skeletal characters were recorded for comparison with other specimens.

\section{Statistical analyses.}

Multivariate patterns in the composition of sponge assemblages were assessed using nonmetric multidimensional scaling (NMDS) ordination. The significance of differences in composition between reefs and habitats were tested using twoway crossed analysis of similarities (ANOSIM). Both these sets of analyses were based on BrayCurtis similarites calculated from untransformed

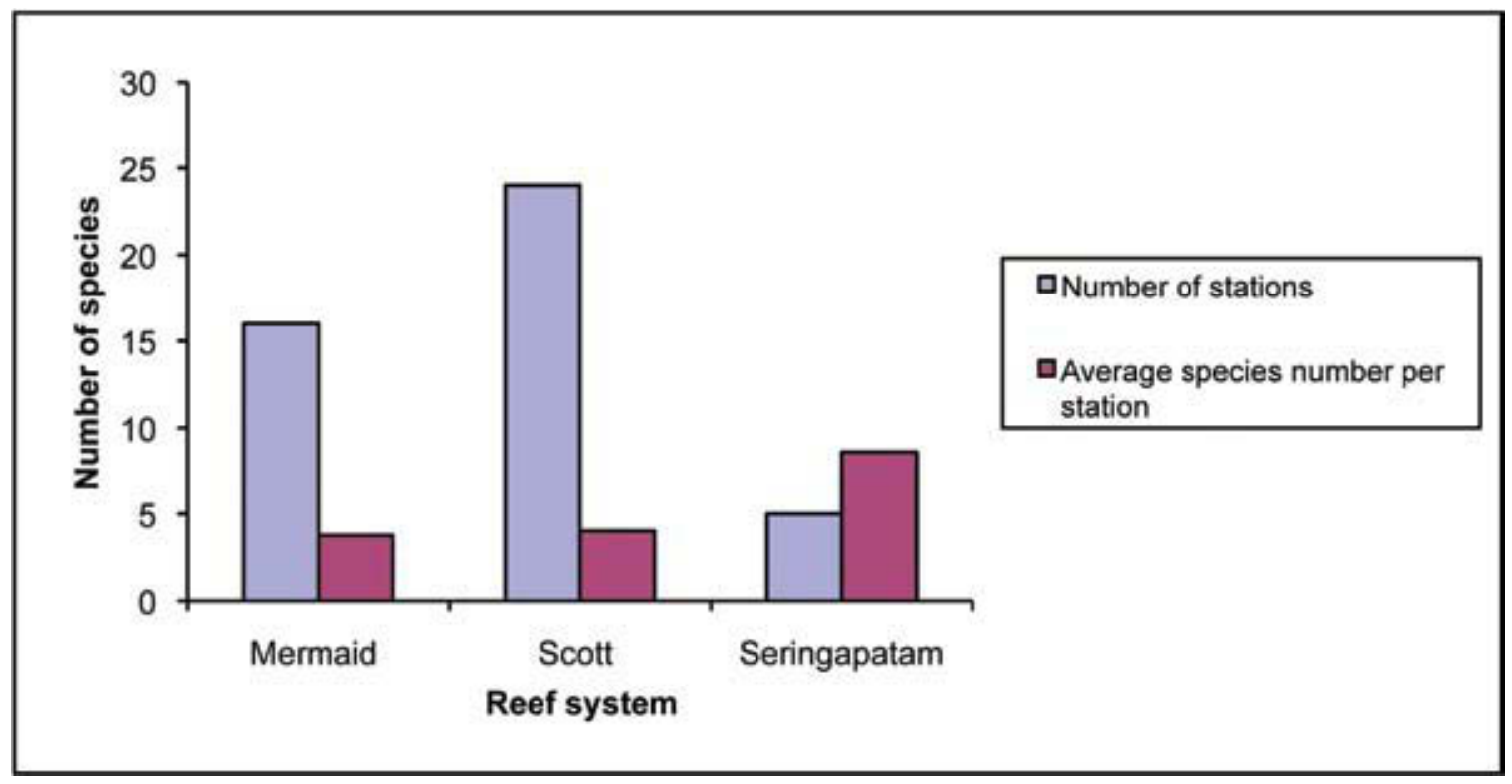

Figure 1 Number of stations per reef system and average number of species per station. 
abundance data. In some analyses we also looked at patterns using presence/absence data (also based on Bray-Curtis similarities) to remove the effect of abundance. Stations that yielded no sponges (stations 6, 37 and one intertidal area at station 3) were excluded prior to analyses. SIMPER analyses were used to identify characteristic species. Multivariate analyses were conducted in the PRIMER statistical package.

Non-parametric methods were used to estimate the total number of species that might occur in the survey area. Three methods were examined to provide a range of diversity estimates: firstand second-order jackknife estimators and the bootstrap estimator (Colwell and Coddington 1994).

\section{RESULTS.}

\section{General patterns.}

One hundred and thirty two species of sponges were collected from the 45 stations examined. The greatest number of species at any reef system was 96 species found at Scott Reef, followed by 60 species at Mermaid and 43 at Seringapatam (Figure $1)$.
This study found a large proportion of the species reported were only found at one of the reef systems. Twenty four species were recorded only at Mermaid Reef, 48 at Scott Reef and 7 at Seringapatam. Therefore a total of 79 species were unique to one of the reefs examined. Only 14 species were widespread and common to all 3 reefs.

A full species list and the reefs where they occurred is provided in Table 1.

Sponges were not recorded from station 6 at Mermaid Reef, but this habitat was dominated by Acropora thickets which are difficult to sample visually for cryptic sponge species. Destructive sampling of the thickets was not undertaken so sponges could have been missed. Intertidal station 37 at Scott Reef did not have any sponges present and consisted predominantly of small boulders covered with algal turf.

Of the 132 species of sponges collected only 29 species $(22 \%)$ could be fully identified with the basic laboratory techniques used (Table 1) and a further 22 species $(17 \%)$ were assigned to a known species but require comparison with type material (signified as cf. in Table 1). The remaining 61\% (81 species) were only able to be assigned to a genus

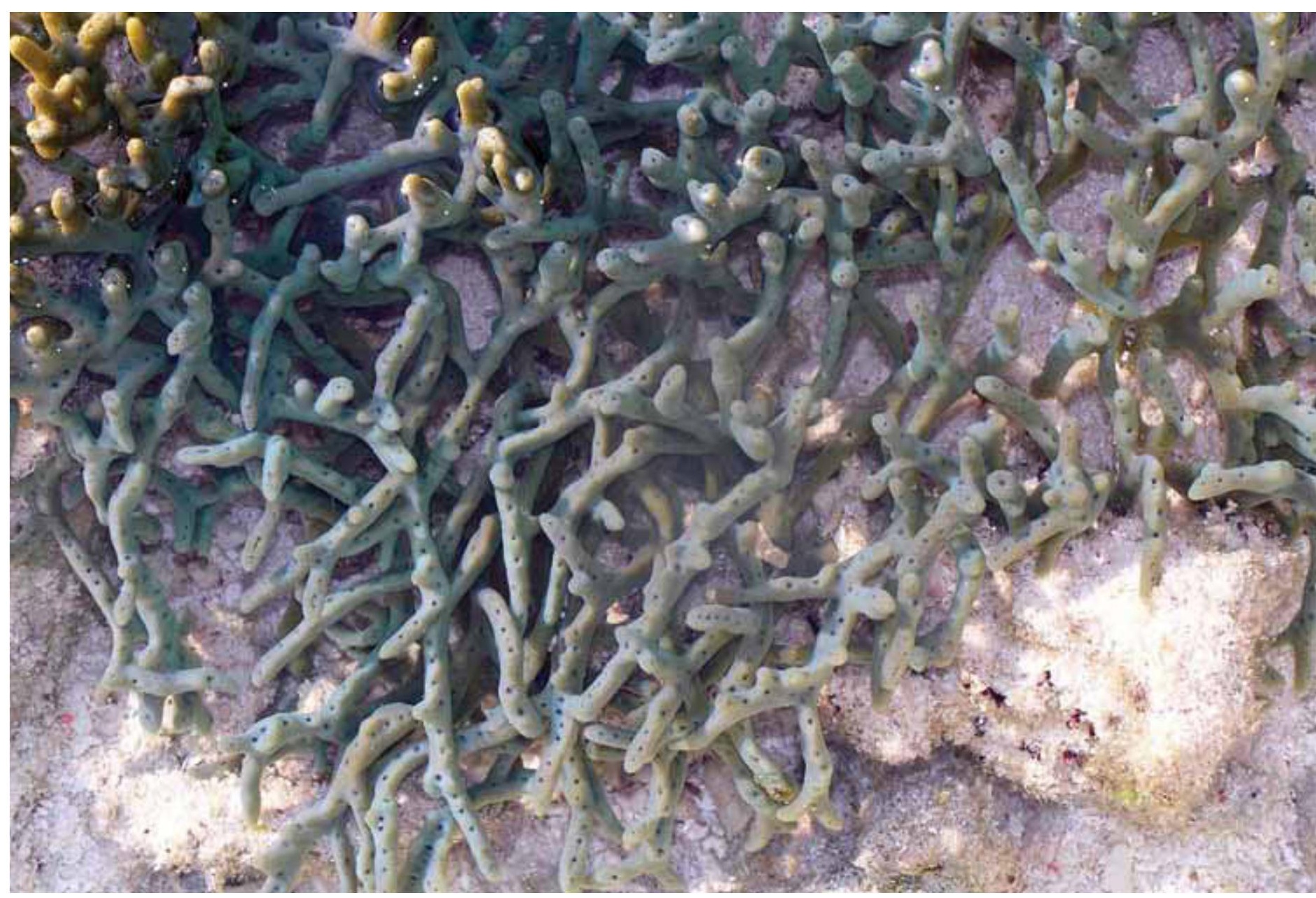

Above: Haliclona koremella de laubenfels 1954. Station 21 South Scott Reef. (Photo: Clay Bryce) 


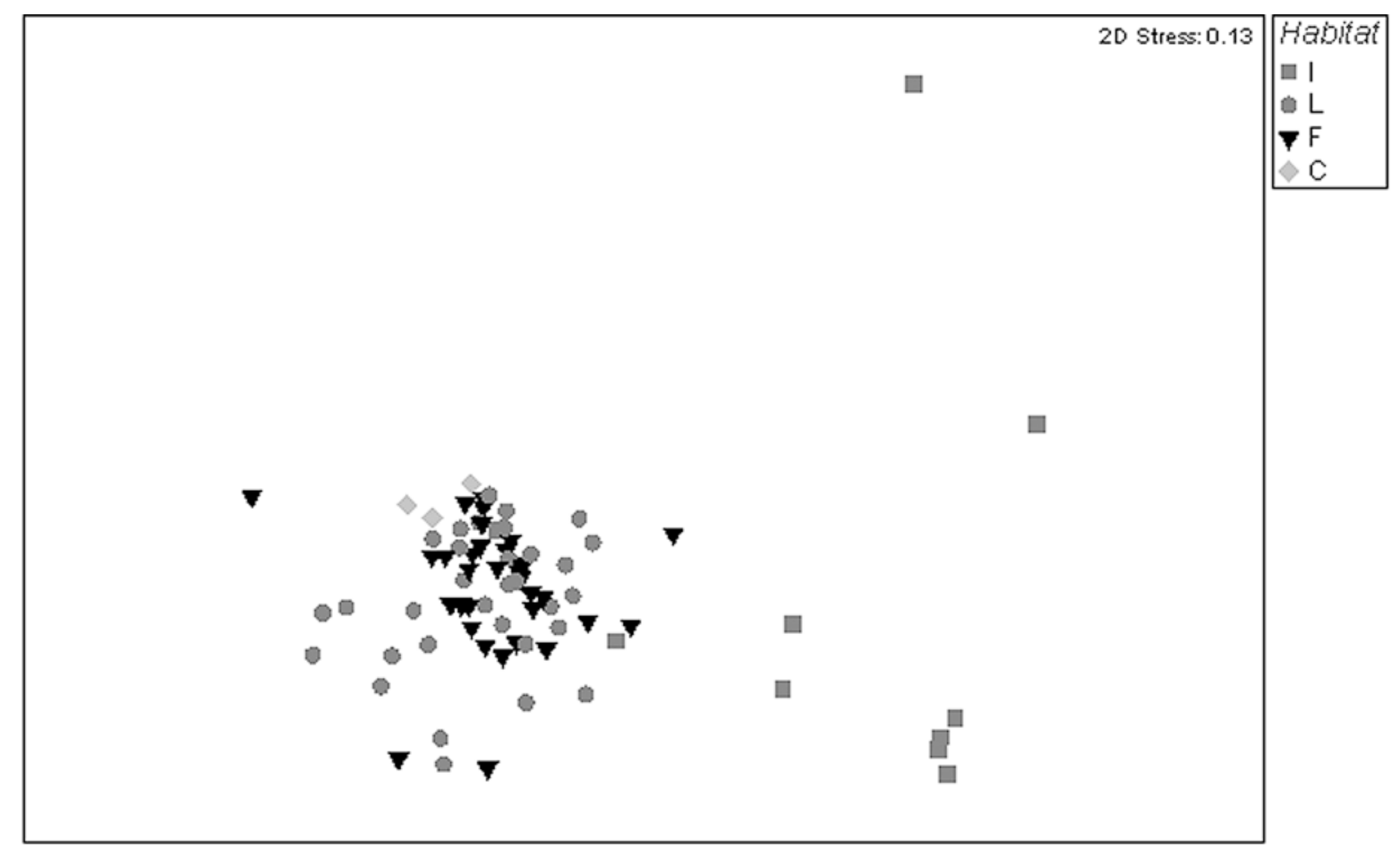

Figure 2 Non-metric multidimensional scaling ordination of all stations surveyed, based on Bray-Curtis similarities calculated from untransformed abundance data ( $\mathrm{I}=$ intertidal, $\mathrm{L}=$ lagoon, $\mathrm{F}=$ fore reef slope, $\mathrm{C}=$ channels).

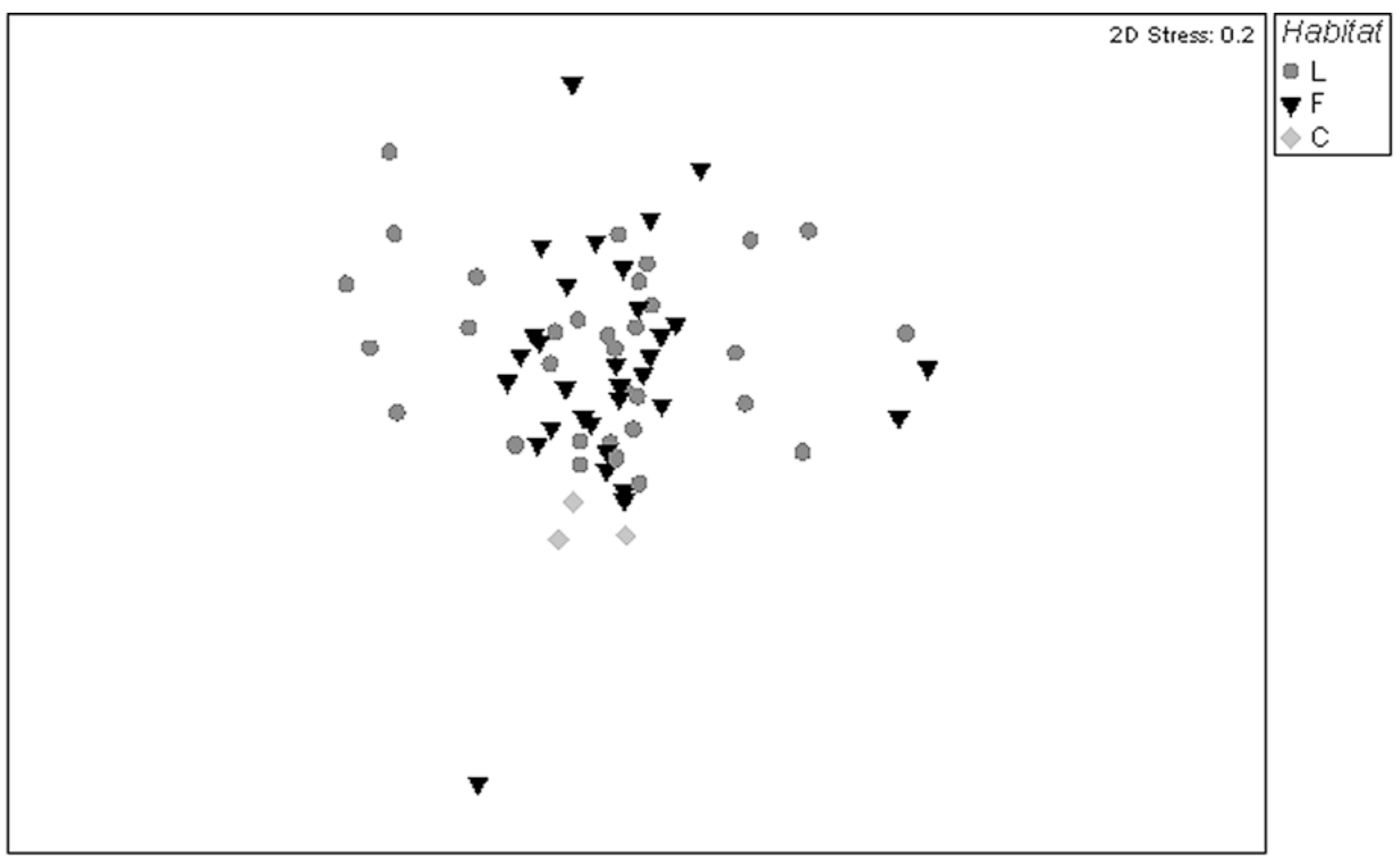

Figure 3 Non-metric multidimensional scaling ordination of subtidal stations surveyed, based on Bray-Curtis similarities calculated from untransformed abundance data, and classified by habitat ( $\mathrm{L}=$ lagoon, $\mathrm{F}=$ fore reef slope, $\mathrm{C}=$ channels). 
and given a species number. These are most likely poorly known species described in old taxonomic literature or are new to science. The 132 species recorded were assigned to 54 genera and 32 families (Table 1).

\section{Patterns in abundance.}

Most of the species reported were rare with 44 of the 132 species (33\%) found at only one station out of the total 45 stations examined in the study. A further 19 species (14\%) were only found at two of the stations surveyed. Furthermore, 74 species (56\% of the total species found) had five or fewer individuals recorded in the total area examined in this study.

Of the 14 species reported at all three reefs, 11 are known to be widespread in the Indo-Pacific. These species are: Plakortis nigra Lévi, 1953, Jaspis splendens (de Laubenfels, 1954), Cliona orientalis Thiele, 1900, Stylissa carteri (Dendy, 1889), Monanchora unguiculata (Dendy, 1922), Gelliodes fibulata (Carter, 1881), Xestospongia exigua (Kirkpatrick, 1900), Neopetrosia testudinaria (Lamarck, 1815), Hyrtios erecta (Keller, 1889), Lamellodysidea herbacea (Keller, 1889) and Pericharax heterorhaphis (Polejaff, 1883).

\section{Patterns in composition.}

The results of the ANOSIM test indicated that the composition of the sponge assemblages across all reefs varied significantly among habitats $(R=$ $0.33, P<0.001)$. However, most of the differences in composition were due to the differences between intertidal stations and subtidal stations, as can be seen in Figure 2. This difference in composition was primarily due to the much lower number of species found at intertidal stations.

When the analysis was repeated without the intertidal stations no clear separation of habitats was visible (Figure 3), although there was still a significant difference among habitats $(\mathrm{R}=0.11, P=$ $0.01)$. Stations in channel habitats were most distinct (pairwise comparisons with lagoon and fore reef $\mathrm{R}$ $>0.27$ ), and were characterised by high abundances of Lamellodysidea herbacea, Cliona orientalis, Jaspis splendens, Haliclona (Reniera) spNW2, Monanchora unguiculata, Dysidea cf. granulosa Bergquist, 1965 and Stelletta clavosa Ridley, 1884 relative to lagoon and fore reef slope habitats.

The composition of the sponge assemblages also varied significantly among reefs ( $R=0.17, P=0.003$ ). When the analysis was performed on presence/ absence data, a clear separation of Scott Reef and Mermaid Reef stations was visible (Figure 4). However, no species were markedly characteristic of either reef.

In the species accumulation curve the number of species recorded did not reach an asymptote, indicating that additional stations would very likely yield more species of sponges (Figure 5). Nonparametric estimates of the total number of species ranged from 156 to 214 (Figure 5). However none of the methods had reached an asymptote, and so these figures should be considered estimates of the minimum number of species that could be present.

\section{DISCUSSION.}

This project has documented the sponge fauna of Mermaid, Scott and Seringapatam Reefs for the first time. The sponge fauna of the oceanic reefs on the northwestern margin of Australia was not known until a study by Hooper (1994), and this present study is the second in the region. This lack of knowledge of a major sessile fauna reflects the still poor state of knowledge of many marine taxa in the vast jurisdiction of Western Australia $(12,500 \mathrm{~km}$ of coastline). Parts of Western Australia have been identified as biodiversity hotspots (Roberts et al., 2002) so the magnitude of the task of documenting the rich marine fauna of the State is massive at a time when the availability of taxonomists in Australia is at its lowest since the early 1900s (FASTS, 2007). Other sessile taxa never studied at these offshore atolls include the ascidians and bryozoa.

Hooper's study and the present study are not directly comparable as Hooper methods were qualitative and ours were quantitative. In addition, this study confined collection and reporting of sponge species from $0-15 \mathrm{~m}$ depth, whilst Hooper's study reported sponges to depths of 30 $\mathrm{m}$. However, the total number of sponge species reported in this study, 132 species from 54 genera and 31 families is similar to the number of species reported by Hooper (1994) from Ashmore, Cartier and Hibernia: 138 species from 77 genera and 38 families. The greater number of genera reported from Hooper's study is now reduced due to recent changes in the taxonomy, for instance a number of the genera are now regarded as subgenera, eg. Microciona, Thalysias, Strongylophora, Adocia, and Reniera, and others have been synonymised, eg. Pseudaxinella, Teichaxinella, Acervochalina, Pellina and Tethyopsilla.

The species accumulation curves in this study indicate that additional species are likely to be found at these reefs. In particular, additional species are likely to occur in deeper waters not surveyed during this study, or at Seringapatam Reef where sampling intensity was lower.

This study found a high number of species unique to one of the three reef systems examined, and Hooper (1994) found that similarity between reefs was low: 13\% similarity between Ashmore and Hibernia, 24\% between Hibernia and Cartier, 


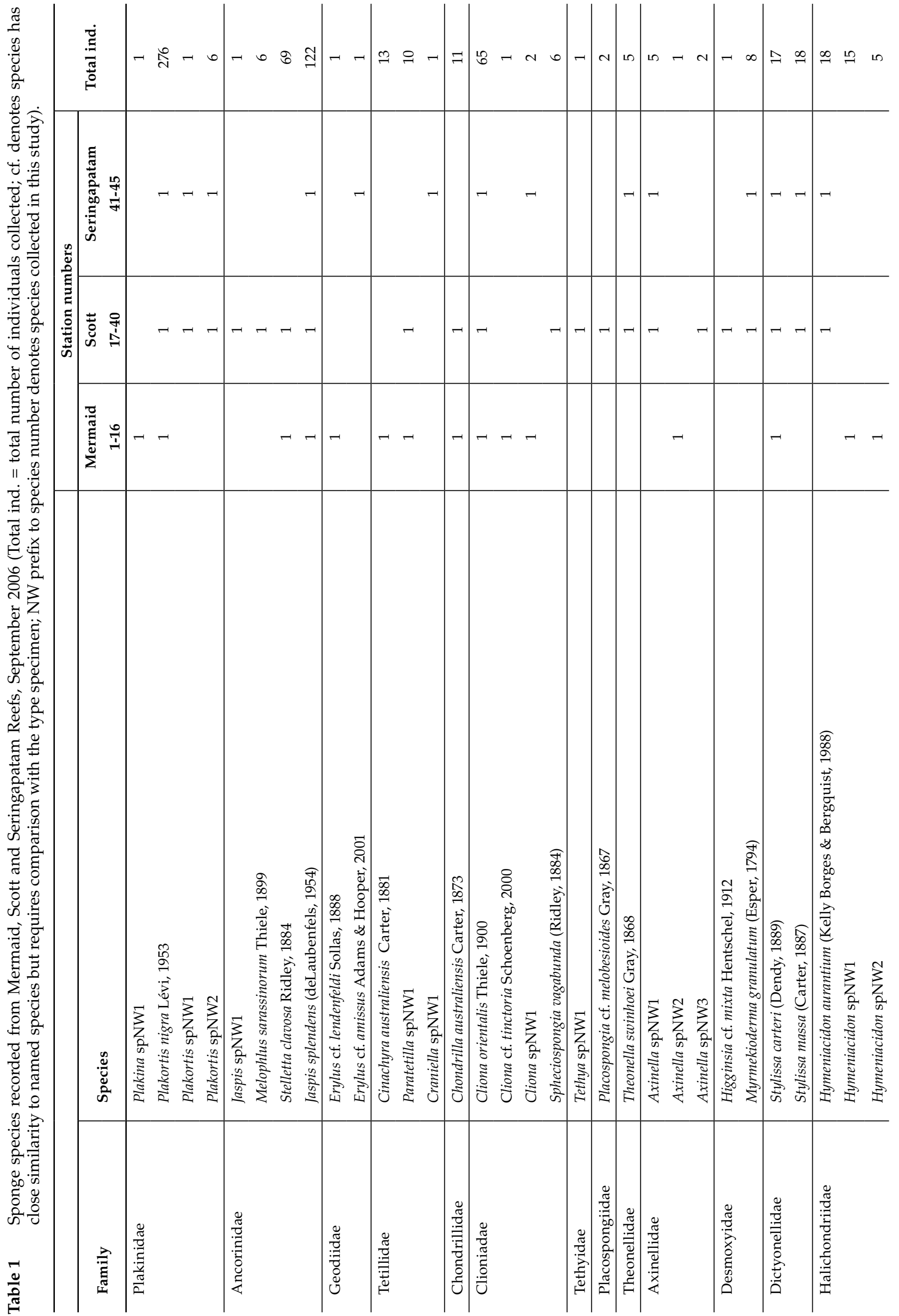




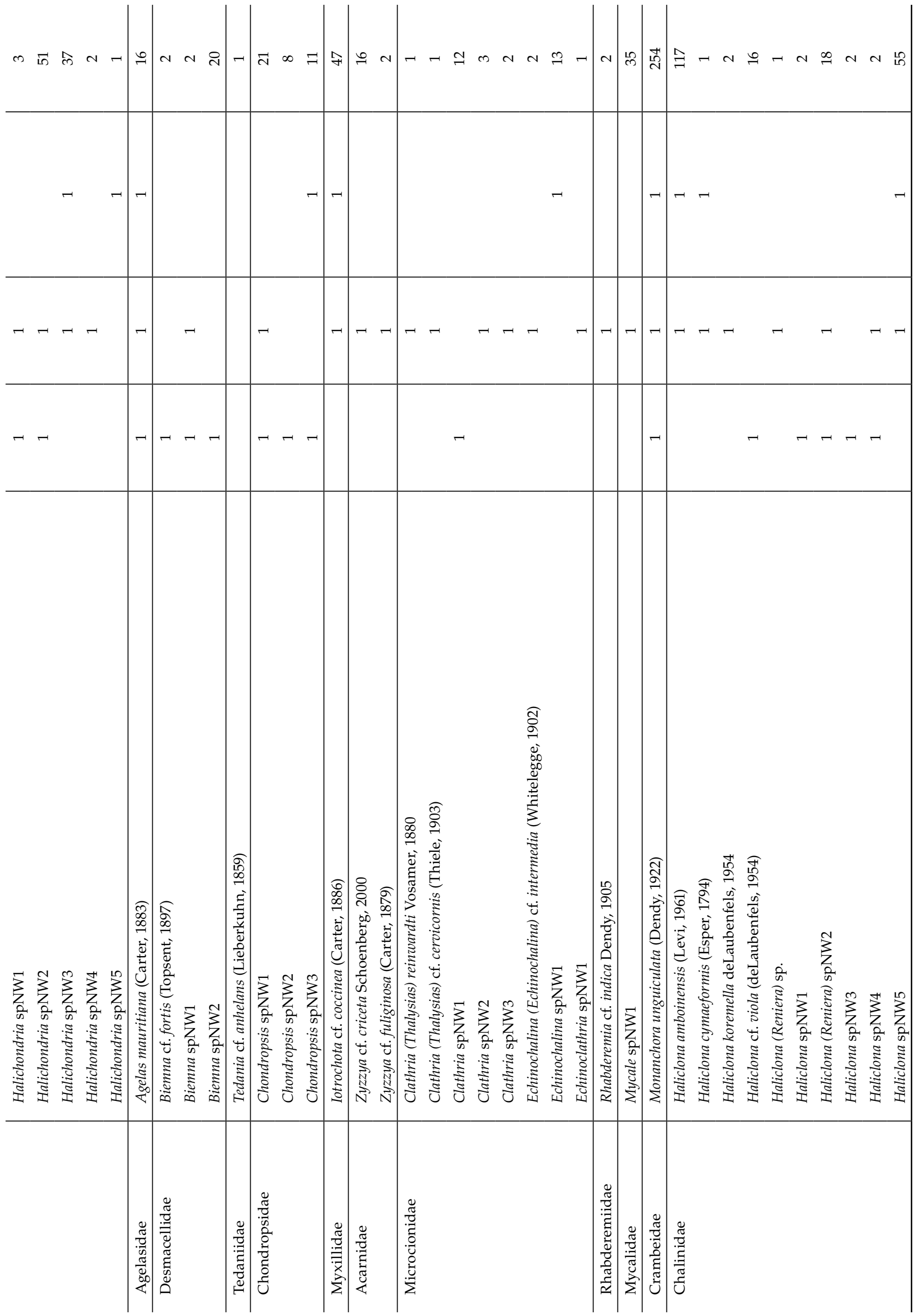




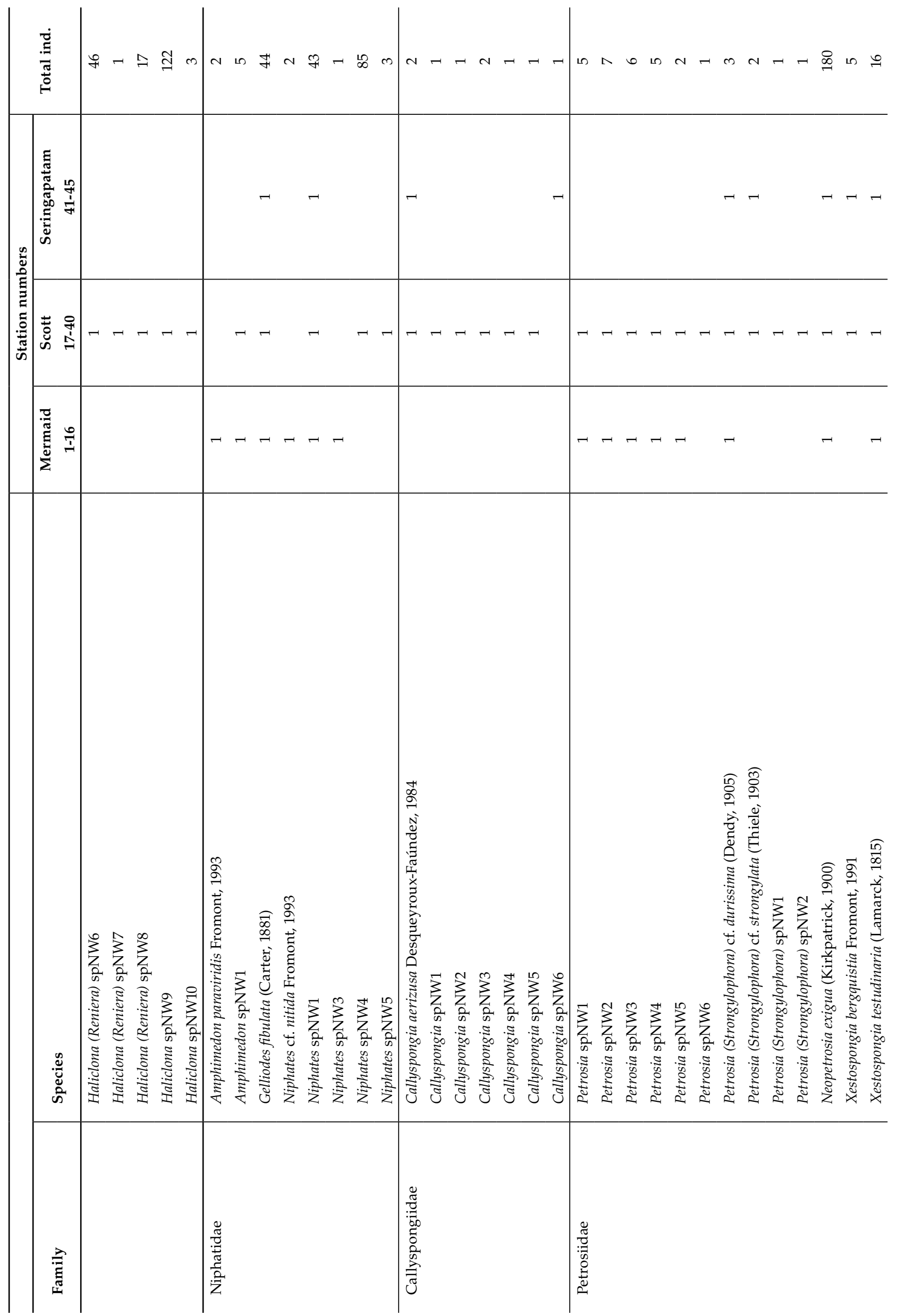




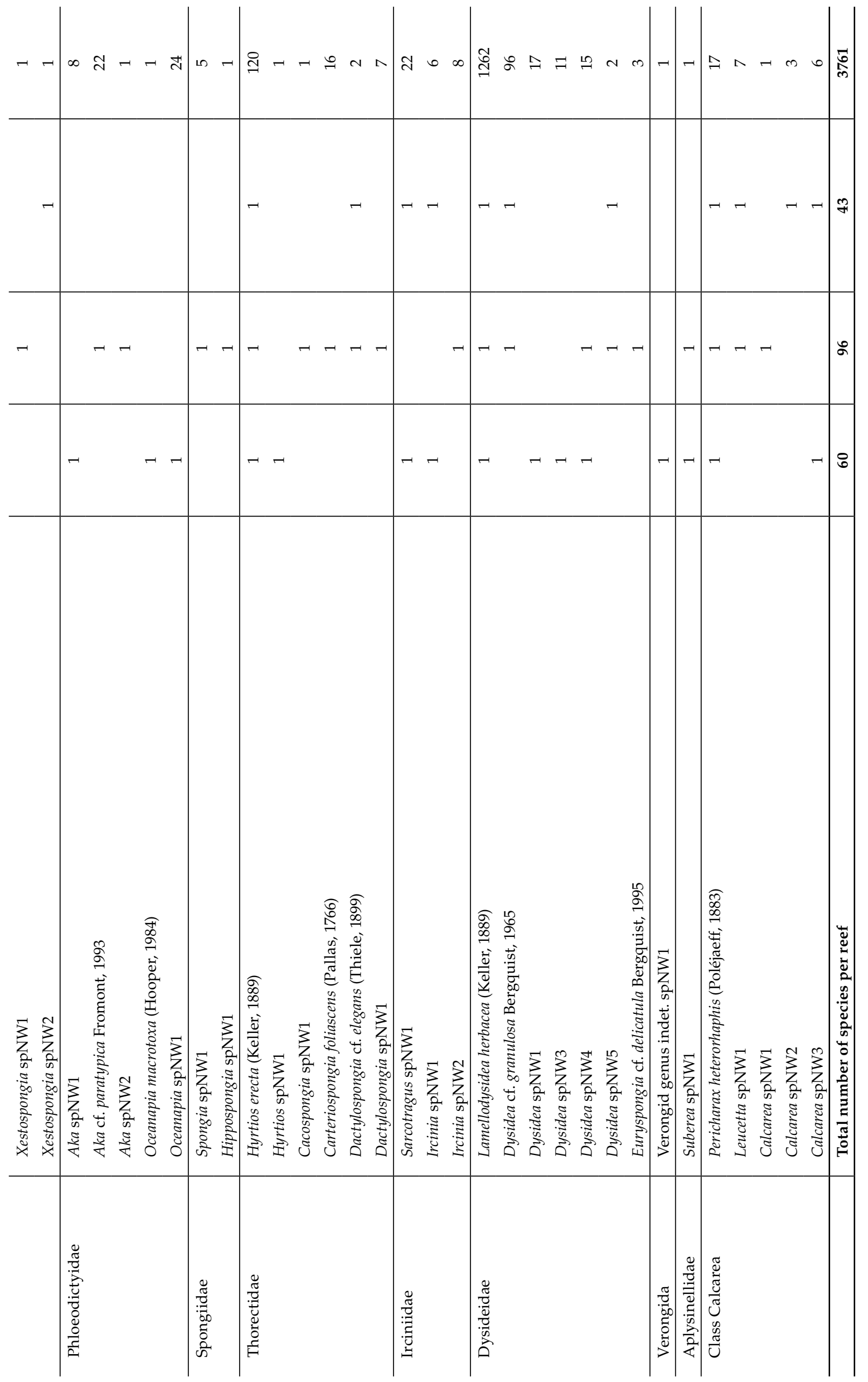




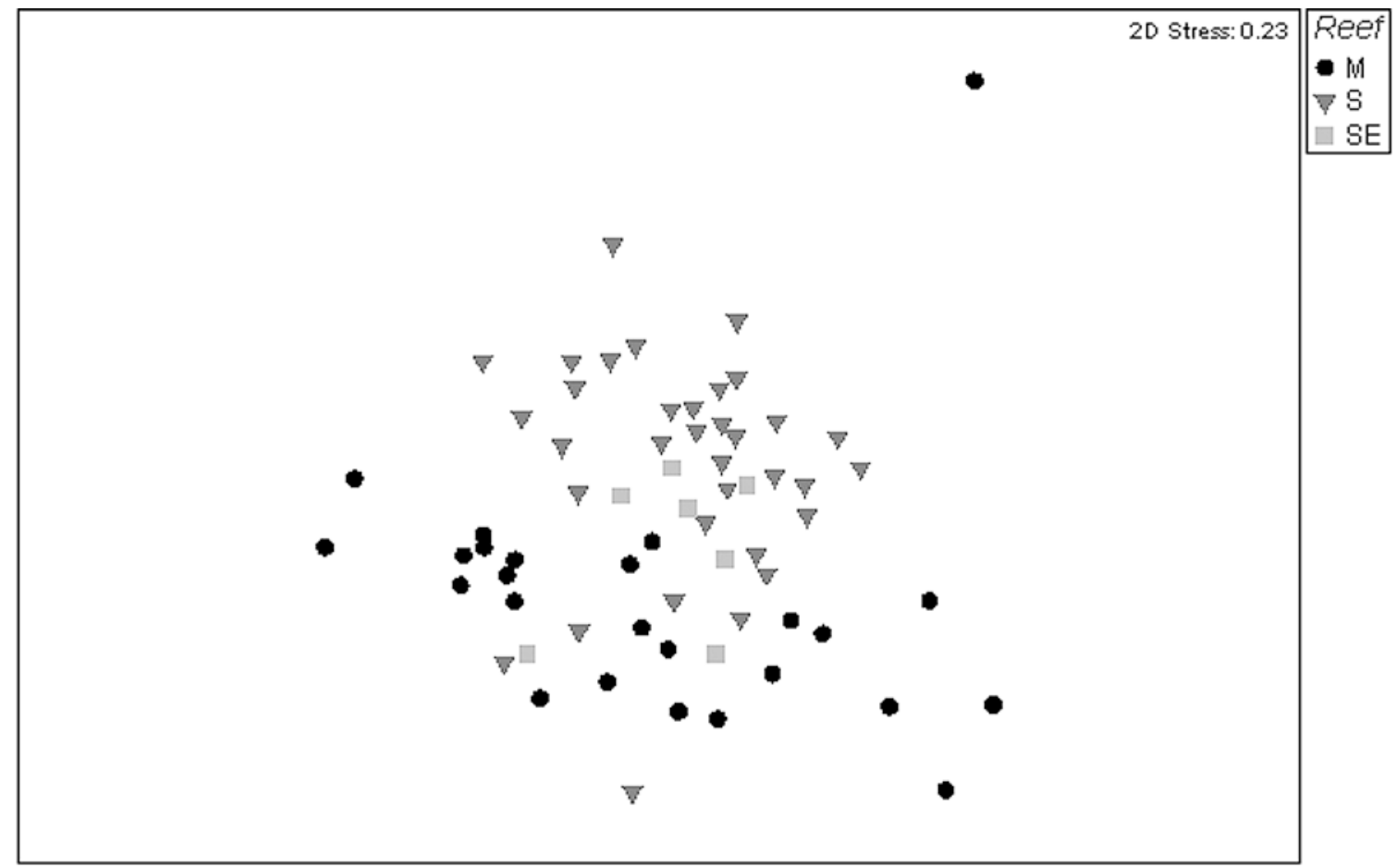

Figure 4 Non-metric multidimensional scaling ordination of subtidal stations surveyed, based on Bray-Curtis similarities calculated from presence/absence data, and classified by reef (M=Mermaid, S=Scott, SE=Seringapatam).

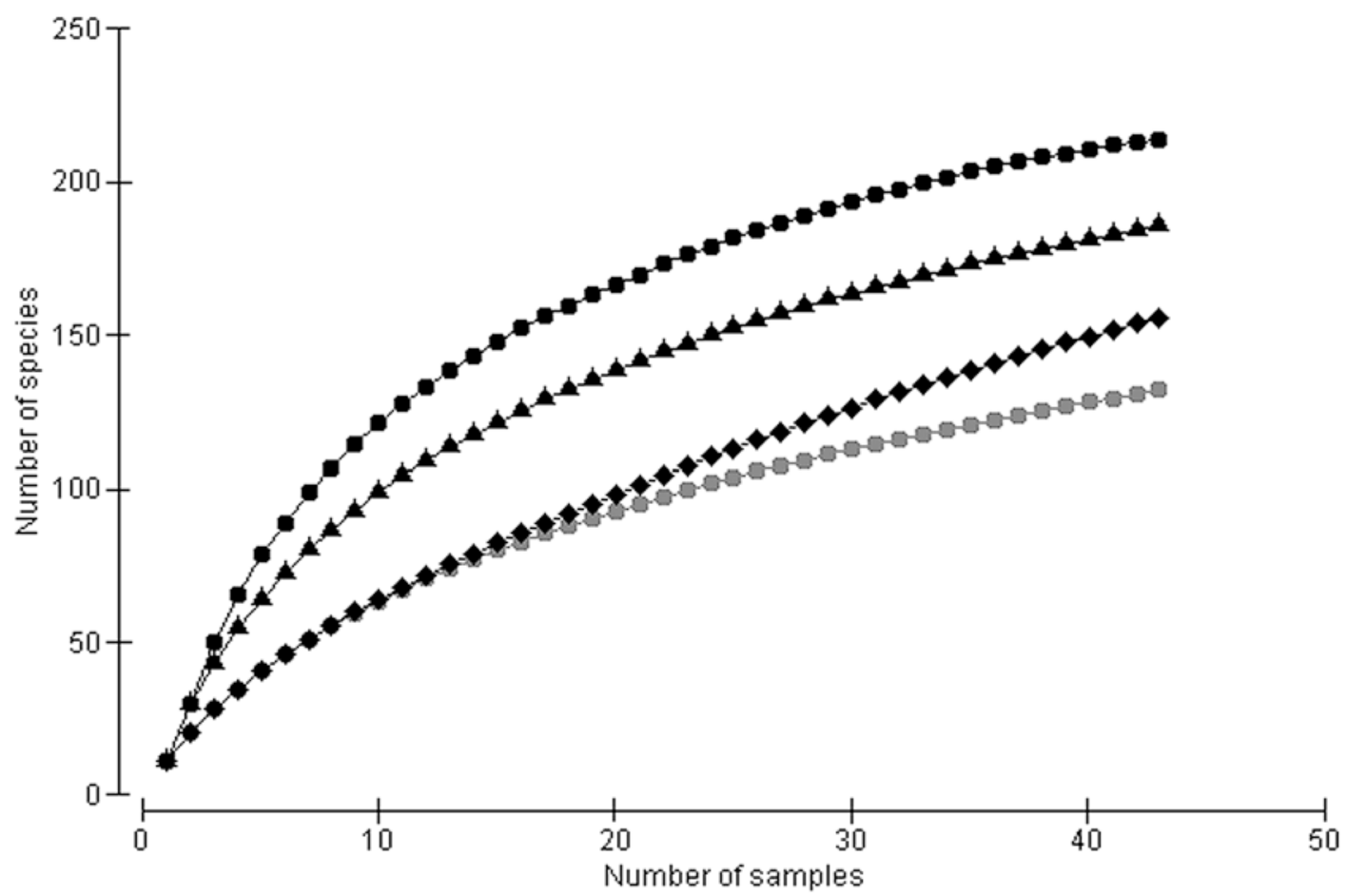

Figure 5 Species accumulation curve (Sobs) and estimated sponge diversity using three methods for estimating species richness. Jacknife1 = first-order jackknife; Jacknife2 = second-order jackknife. 


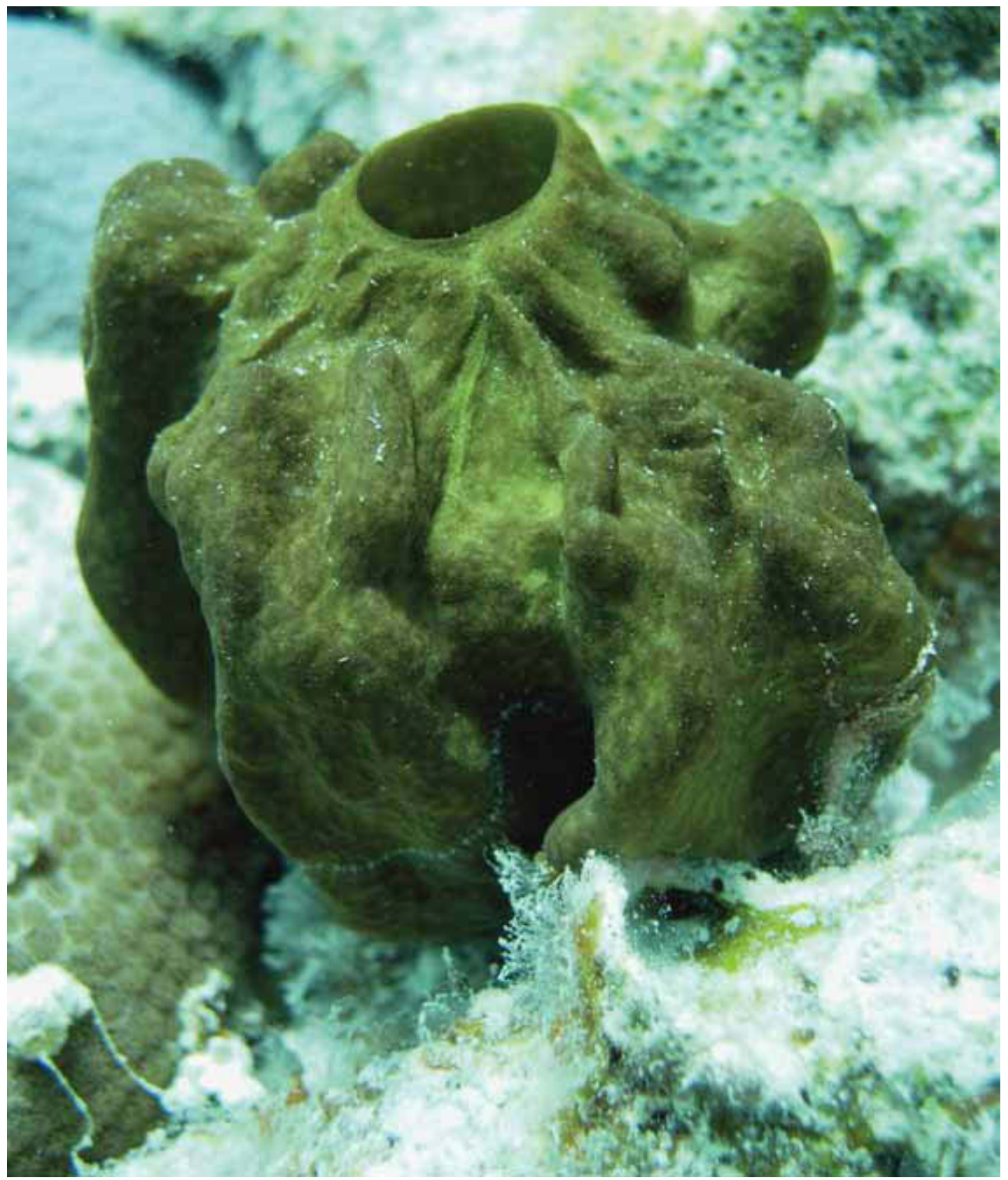

Above: Pericharax heterorhaphis Poléjaeff, 1833: The most common calcareous sponge in the shallow subtidal at station 32, North Scott Reef. (Photo: John Huisman)

rarity of sponge species, it is likely to make these species vulnerable to environmental perturbations that may increase in occurrence with the impacts of climate change.

Some sponge species are capable of asexual modes of reproduction (Hooper, 1994), and this may, in part, explain the incidence of the few species (14 species) occurring at all three reefs.

Examination of sponge assemblages between habitats found that intertidal stations were distinctive, in large part due to the low sponge species richness in these habitats. Intertidal habitats at these reefs are extreme environments for sponges with low nutrient waters that get very warm in summer (up to $31^{\circ} \mathrm{C}$, McKinney, pers. comm). Analysis of subtidal habitats found channels were distinctive from fore reef slope and lagoon habitats, due to high abundances of a few common species. These species tended to be encrusting or low-lying and thus able to withstand extreme flows that occur in high energy channel habitats (Bell et al., 2006). Fore reef slope and lagoon habitats appeared to host similar species assemblages which included some of the more common species such as: Plakortis nigra, Stelletta splendens, Monanchora unguiculata, Gelliodes fibulata, Xestospongia testudinaria and Hyrtios erecta.

The preliminary nature of the species identifications does not allow for a detailed analysis 
of the species recorded and their biogeographic affinities. An enormous amount of detailed taxonomic work is required to determine if the species have been described in the historic tropical Indo-Pacific and Indian Ocean sponge literature, and to complete the identifications and describe the new species.

A large proportion of species from this and Hooper's study (81 and 77 species respectively) were not identified to known species making comparisons between the studies difficult. However, of the species that were fully identified (51 in this study and 61 in Hooper's study) only nine species were common to both studies. This finding supports the suggestion that the majority of sponge species are localized in their distributions.

A preliminary examination of the biogeography found that some of the common Indo-Pacific species that have been found at higher latitudes on the west coast (Dampier: Fromont, 2003) and during the collections undertaken at Ashmore, Cartier and Hibernia reefs (Hooper, 1994), were not found at the reefs examined in this study. No species of the genus Ianthella were found although the highest diversity of this genus is reported to be in tropical north-west Australia (Kelly Borges and Bergquist,
1995). Species of Ianthella were reported from Cartier and Hibernia by Hooper (1994) and Fromont (2003) in the Dampier Archipelago. A similar disjunction in species distributions is also apparent for other Indo-Pacific species such as: Rhabdastrella globostellata (Carter, 1883), Reniochalina stalagmitis Lendenfeld, 1888 , Clathria (Microciona) aceratoobtusa (Carter, 1887), and species of Ectyoplasia and Echinodictyum. Perhaps these species occur only in waters deeper than $15 \mathrm{~m}$ on these oceanic atolls, more shallow stations needed to be sampled to detect them, or they may not occur at these reefs. Only additional sampling at deeper depths and additional stations at shallow depths would determine if these species do occur at these atolls but were not found in this study.

Hooper (1994) also noted the presence of autotrophic sponges (capable of harnessing energy from symbiotic light requiring organisms resident in their tissues) at all three reefs he examined. These sponges were also found in this study with many of them being locally abundant. Autotrophic species reported from this study include Lamellodysidea herbacea, Pericharax heterorhaphis, Chondrilla australiensis Carter, 1886, Haliclona cymaeformis (Esper, 1794) and Haliclona

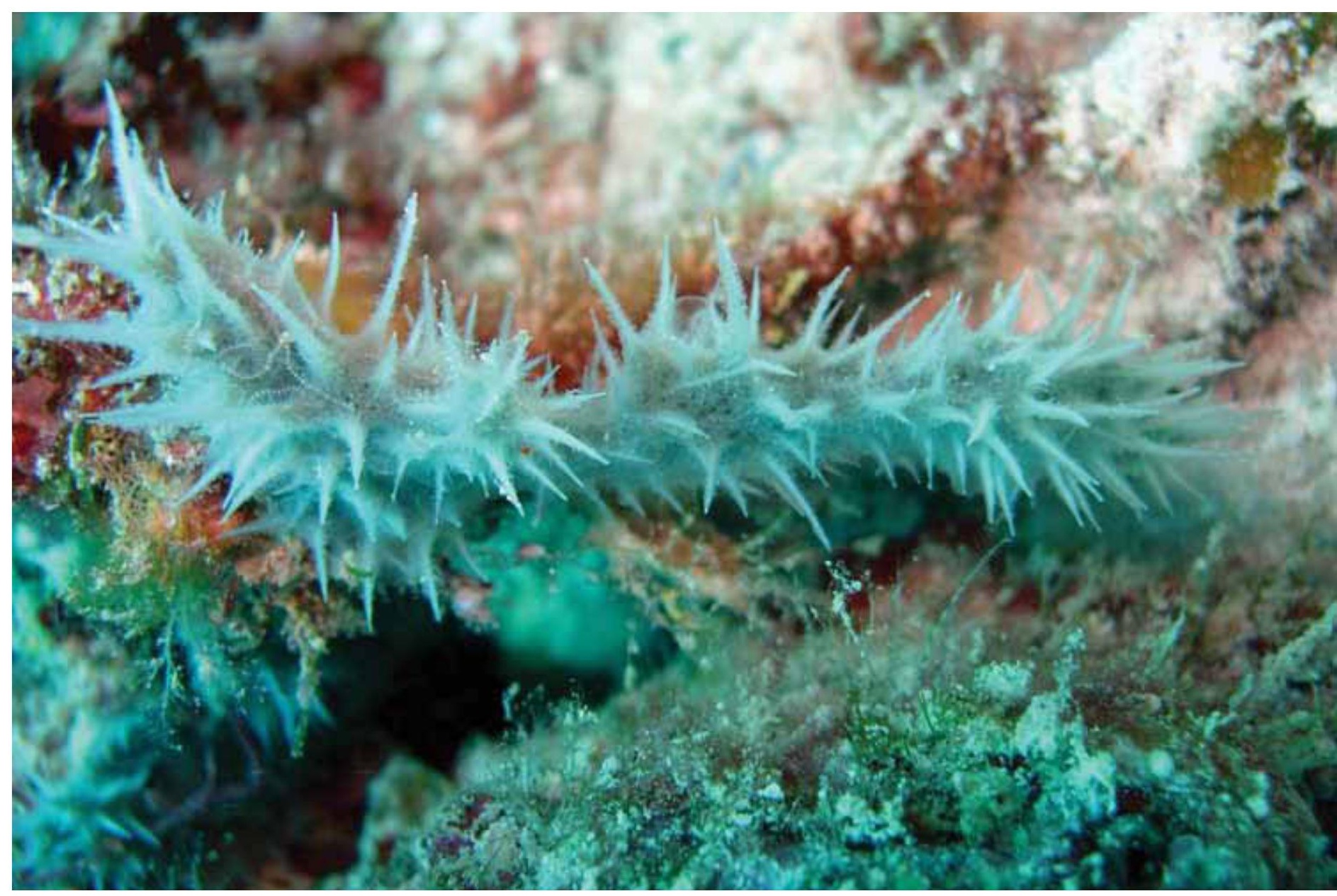

Above: Gelliodes fibulata (Carter, 1881) at station 31, North Scott Reef. (Photo: John Huisman) 


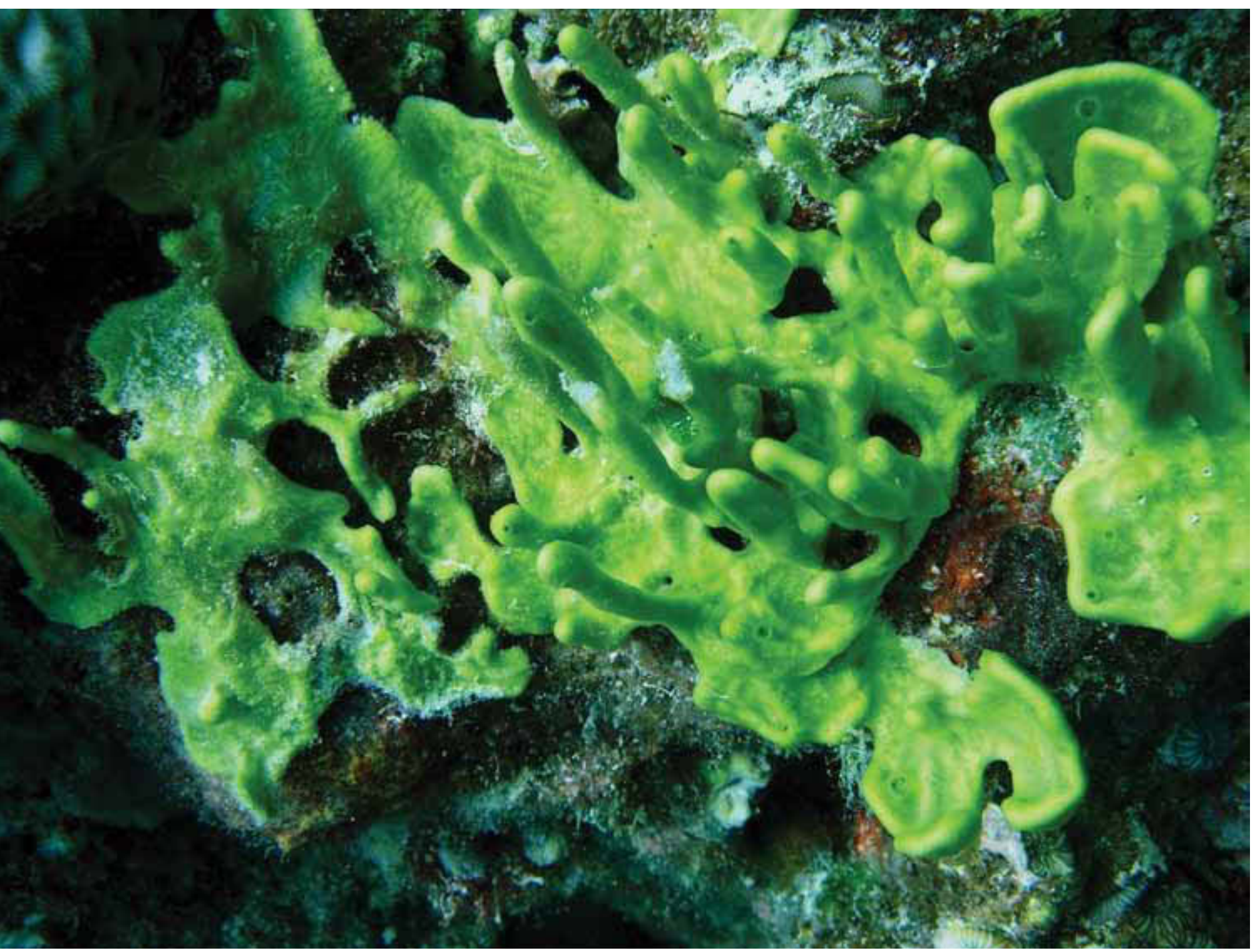

Above: Dysidea in the shallow subtidal at station 26, South Scott Reef. (Photo: John Huisman)

koremella de Laubenfels, 1954. These symbioses are thought to enhance sponge growth rates and competitiveness in tropical shallow water environments (Wilkinson and Cheshire, 1989). Recently autotrophic sponges have been found to have an increased incidence in shallow tropical environments (Rutzler and Muzik, 1993) and may be competitive with other light requiring organisms (corals and clams) susceptible to bleaching. This study has documented abundance data for these sponges and may provide an important baseline for future monitoring of these coral reef sponges.

Other sponge species are known to infiltrate coral and these calcium carbonate bioeroders are thought to be increasing in incidence in some coral reef areas (Caribbean: Rutzler, 2002; Great Barrier Reef: Schoenberg, pers. comm). Four species of excavating sponges were reported in this study, and quantitative data on their distribution in these reefs is now available. The Indo-Pacific species, Cliona orientalis, is presently abundant (65 individuals found in this study), and the other three species are rare (between 1 to 6 specimens found in this study).

In conclusion, this study has documented the sponge fauna of three oceanic reefs in north Western Australia for the first time. Quantitative data are available to form a sound baseline for any future monitoring of these sponge species distributions and abundances.

\section{ACKNOWLEDGEMENTS}

Jane Fromont thanks the crew of the Kimberley Quest for their assistance during the expedition. Clay Bryce, Sue Morrison and Glenn Moore (Western Australian Museum) and John Huisman (Department of Environment and Conservation) kindly provided in situ images of sponges. Thanks to Yuki Konishi who thoroughly crosschecked data entry, and Oliver Gomez and Mark Salotti who provided technical and logistical support for this work. 


\section{REFERENCES.}

Bell, J. J., Burton, M., Bullimore, B., Newman, P.B., Lock, K. (2006). Morphological monitoring of subtidal sponge assemblages. Marine Ecology Progress Series 311: 79-91.

Colwell R.K., Coddington J.A. (1994). Estimating terrestrial biodiversity through extrapolation. Philosophical Transactions Royal Society London. B 345: 101-118.

FASTS, (2008). Federation of Australian Scientific and Technological Societies (2008). Proceedings of the National Taxonomy Forum. 4-5 October 2007. Australian Museum, Sydney NSW.

Fromont J. (2003). Porifera (Sponges) in the Dampier Archipelago: taxonomic affinities and biogeography. In: Wells F.E., Walker D.I. and Jones D.J. (eds), Proceedings of the Twelfth International Marine Biological Workshop. The Marine Flora and Fauna of Dampier, Western Australia. Western Australian Museum, Perth, 2: 405-417.

Fromont, J. Vanderklift, M.A. Kendrick, G. A. (2006). Marine sponges of the Dampier Archipelago, Western Australia: patterns of species distributions, abundance and diversity. Biodiversity and Conservation 15: 37313750 .

Kelly Borges, M. and Bergquist, P. R. (1995). Systematics and biogeography of the genus Ianthella (Demospongiae: Verongida: Ianthellidae) in the South-west Pacific. The Beagle, Records of the Museums and Art Galleries of the Northern Territory 12: 151-176.

Heyward, A.J., Smith, L., Halford, A.R., Rees, M., and Meekan, M. (1999). Natural variability at Scott Reef: short term response of coral and fish assemblages to a severe coral bleaching event. Dampier: Australian Institute of Marine Science.

Hooper, J.N.A. (1994). Coral reef sponges of the Sahul Shelf - a case study for habitat preservation. Memoirs of the Queensland Museum 36(1): 93-106.

Hooper, J.N.A., Kennedy, J. A. and Quinn, R.J. (2002). Biodiversity 'hotspots', patterns of richness and endemism, and taxonomic affinities of tropical Australian sponges (Porifera). Biodiversity and Conservation 11: 851-885.

Maldonado, M. and Bergquist, P.R. (2002). Chapter 2. Phylum Porifera. In: Atlas of Marine Invertebrate Larvae: 21-50.

McQuillan, L. (2006). Species Richness, Density and Cover of Sponges On Temperate Reefs In Western Australia. Unpublished MSc thesis, Edith Cowan University.

Rutzler, K. (2002). Impact of crustose clionid sponges on Caribbean reef corals. Acta Geologia Hispanica 37: 61-72.

Rutzler, K., and Muzik, K. (1993). Terpios hoshinata, a new cyanobacteriosponge threatening Pacific reefs. Scientia Marina 57(4): 395-403.

Wilkinson, C.R. and Cheshire, A.C. (1989). Patterns in the distribution of sponge populations across the central Great Barrier Reef. Coral Reefs 8: 127-134.

Zea, S. (2001). Patterns of sponge (Porifera, Demospongiae) distribution in remote, oceanic reef complexes of the southwest Caribbean. Revista de la Academia Colombiana de Ciencias Exactas, Fisisca y Naturales 25: 579-592. 


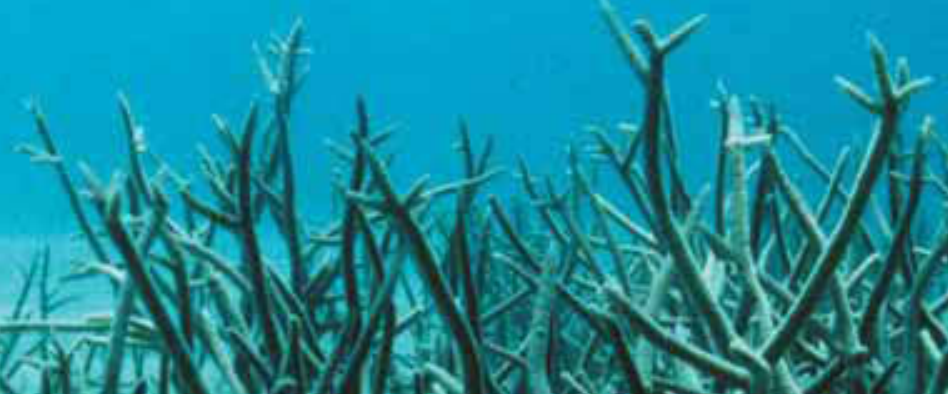

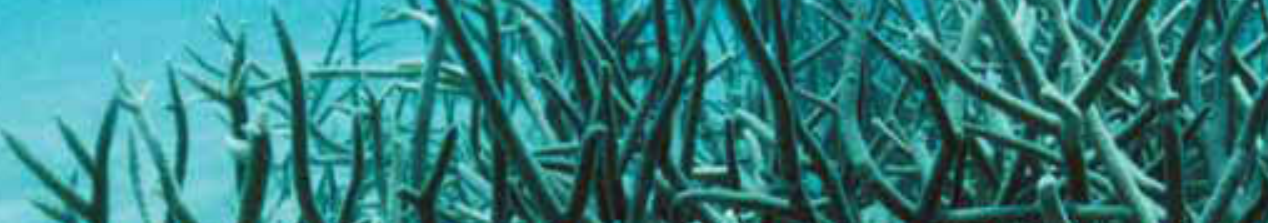

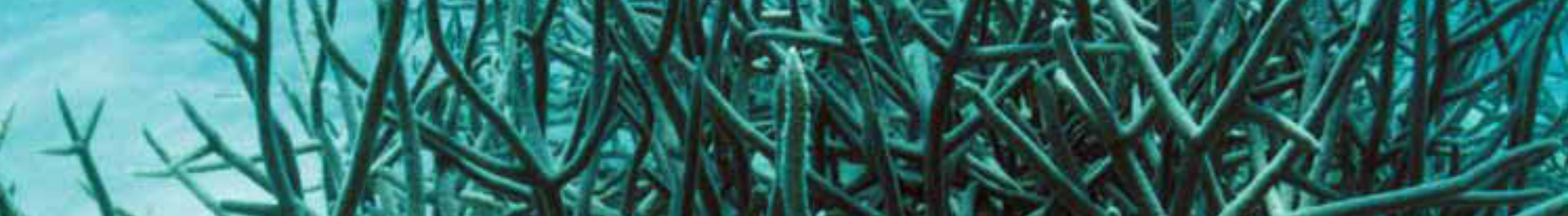

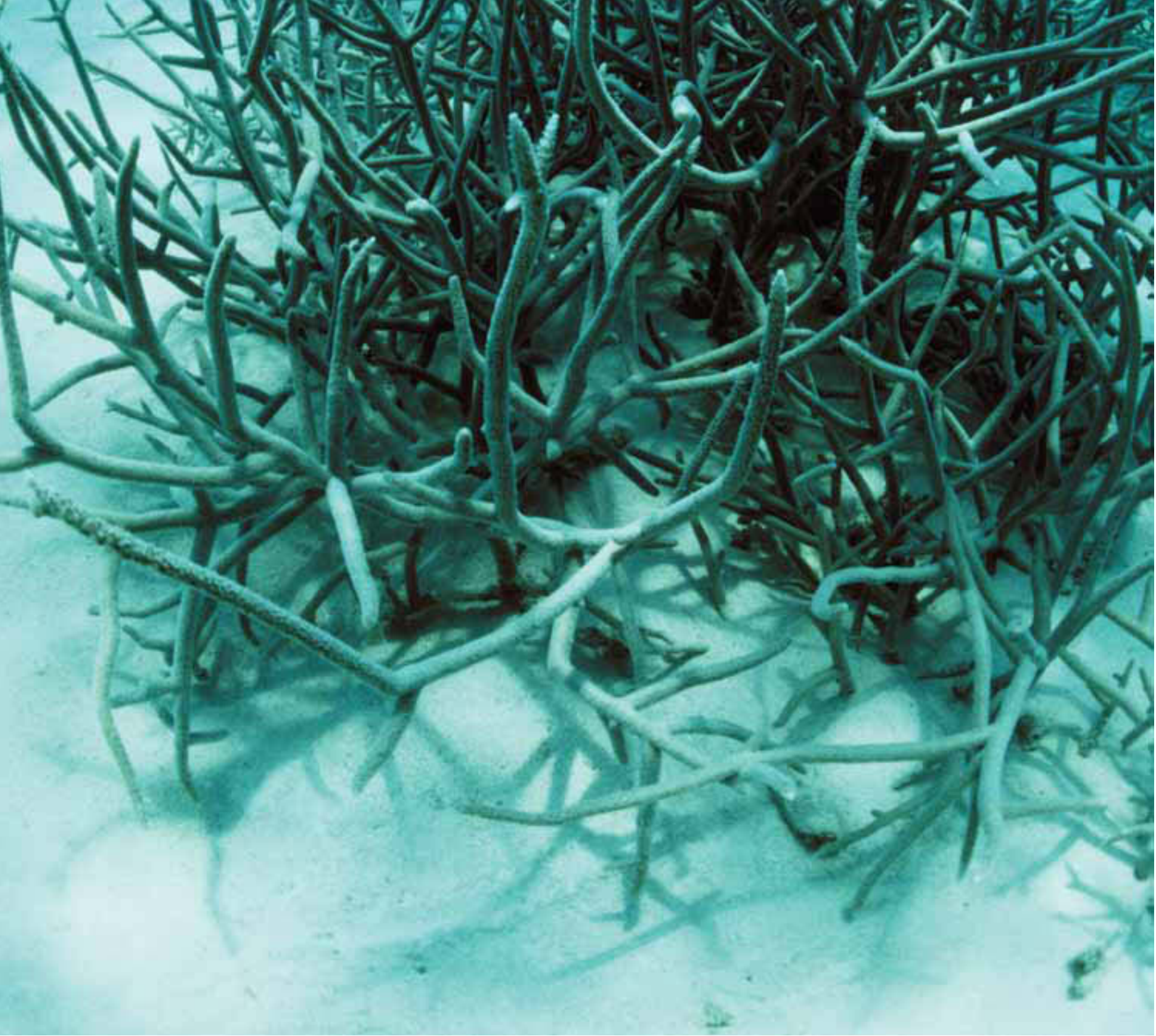

Above: Seringapatam Reef. An Acropora colony on a sand inundated reef probably caused from cyclonic activity. (Photo: Clay Bryce) 